\section{Management of trypanosomiasis in a tigress Panthera tigiris: a case report}

\section{Atul Gupta ${ }^{1}$, Kajal Jadav $^{2}$, Jasbir Singh Chouhan ${ }^{3}$ \& Parag Nigam ${ }^{4}$}

\begin{abstract}
${ }^{1}$ Veterinary Officer, Van Vihar National Park (VVNP), Bhopal, Madhya Pradesh, India

${ }^{2}$ Veterinary Officer, Van Vihar Bear Rescue Facility, Wildlife S.O.S, VVNP, Bhopal, Madhya Pradesh, India

${ }^{3}$ Ex-Director, VVNP, Bhopal, Madhya Pradesh, India

${ }^{4}$ Senior Lecturer, Department of Wildlife Health Management, Wildlife Institute of India, Dehradun, Uttarakhand 248001, India Email: ${ }^{1}$ dratulgupta2000@ rediffmail.com; ${ }^{4}$ nigamp@ @ii.gov.in (corresponding author)
\end{abstract}

Trypanosoma evansi is an important protozoan parasite of mammals that is transmitted by haematophagous flies (Veer et. al. 2002) of the genera Tabanus, Stomoxys (Parashar et al. 2006), Haematopota, Liperosia and Chrysops (OIE 2005). The parasite is pathogenic to both domestic and wild animals and may affect more than 30 wild animal species (OIE 2005). The disease is endemic in the Indian subcontinent, with recent reports of mortalities in zoos in Lahore (Pakistan) and Dhaka (Bangladesh). Major outbreaks as well as sporadic cases of trypanosomiasis have been reported in tigers in captivity in India (Ziauddin et al. 1992; Singh et al. 1997; Parija \& Bhattacharya 2001). Wild carnivores infected with trypanosomes may display typical signs similar to those exhibited by domestic species, or may succumb without showing any signs. The major clinical findings include fever, anemia, weight loss, edema, lymphadenomegaly, uncoordinated movements (gait) and sudden death.

The present communication reports a case of trypanosomiasis in a tigress and response to quinapyramine therapy at Van Vihar National Park, Bhopal (Madhya Pradesh) during January 2008.

Area details: Van Vihar National Park lies between $23^{\circ} 20^{\prime} 86^{\prime \prime}-23^{\circ} 20^{\prime} 89^{\prime \prime} \mathrm{N} \& 77^{\circ} 15^{\prime} 144^{\prime \prime}-77^{\circ} 15^{\prime} 10^{\prime \prime} \mathrm{E}$ along the banks of Upper Lake, Bhopal, Madhya Pradesh. Animal housings are located on a hilly plateau, with an individual kraal of $40 \times 28 \mathrm{~m}$ attached to a feeding and retiring den of

Date of publication (online): 26 October 2009

Date of publication (print): 26 October 2009

ISSN 0974-7907 (online) | 0974-7893 (print)

Editor: Jacob V. Cheeran

Manuscript details:

Ms \# 02197

Received 06 May 2009

Final received 19 June 2009

Finally accepted 23 September 2009

Citation: Gupta, A., K. Jadav, J.S. Chouhan \& P. Nigam (2009). Management of trypanosomiasis in a tigress Panthera tigiris: a case report. Journal of Threatened Taxa 1(10): 538-540.

Copyright: (c) Atul Gupta, Kajal Jadav, Jasbir Singh Chouhan \& Parag Nigam 2009. Creative Commons Attribution 3.0 Unported License. JoTT allows unrestricted use of this article in any medium for non-profit purposes, reproduction and distribution by providing adequate credit to the authors and the source of publication.

OPEN ACGESS | FREE DOWNLOAD

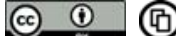

$2.2 \times 3.3 \mathrm{~m}$ with provision for manual restraint. Housings are separated by concrete walls.

Case history: An adult tigress Priya aged about eight years and weighing approximately $100 \mathrm{~kg}$ exhibited signs of inappetence, anorexia, dullness and depression for 24 hours. The animal was shifted to a squeeze cage and restrained for physical examination. Physiological parameters were monitored and revealed rapid and shallow respiration ( 78 breaths per minute), elevated heart rate ( 110 beats per minute) and increased rectal temperature $\left(104^{\circ} \mathrm{F}\right)$.

Methods: About 10ml of blood was collected from the tail vein and placed in a heparinized vacutainer for haematological analysis and in a plain vacutainer for serum biochemical analysis. A scat sample was also collected for parasitological examination. The samples were sent to the State Disease Investigation Laboratory, Bhopal for further haematobiochemical examinations including total erythrocyte count (TEC), total leucocyte count (TLC), differential leucocyte count (DLC), packed cell volume (PCV), haemoglobin concentration, serum calcium, inorganic phosphorus, creatinine, bilirubin (total and direct) in addition to estimating serum proteins and enzymes, chiefly alanine amino transferase (ALT), aspartate amino transferase (AST) and alkaline phosphatise (ALP) (Coles 1986). Mean corpuscular volume (MCV), mean corpuscular haemoglobin $(\mathrm{MCH})$ and mean corpuscular haemoglobin concentration (MCHC) were calculated by the formula as described by Swenson \& Reece (1996). Wet blood mounts were examined directly; the dried blood smear was stained by Giemsa stain (Schalm et al. 1975) for differential leucocyte count and examination of blood parasites.

Result and Discussion: The stained blood smear and wet mounts revealed the presence of trypomastigotes indicative of Trypanosoma infection. The species of trypanosome could not be determined due to non-availability of immunodiagnostic tests. Coprological examination did not reveal any parasitic ova. The animal was treated with Triquin (quinapyramine sulphate and quinapyramine chloride; Wockhardt Limited) in addition to fluid and supportive therapy. Antibiotic cover was provided to avoid secondary bacterial infection. Treatment provided is summarized in Table 1. The tigress was provided with small quantities of mutton soup and glucose water initially while solid food was withheld for 24 hours. Body temperature began to recede by 24 hours and reached normal $\left(101.5^{\circ} \mathrm{F}\right)$ by the end of the second day. The animal showed signs of recovery after 48 hours as manifested by consuming about $6 \mathrm{~kg}$ of buffalo meat, alertness, normal gait and normal defecation and micturation. Blood samples were again collected for examination after 48 hours of treatment and tested negative for haemoprotozoans. Blood profiling was done after a month and the details of the laboratory analysis are tabulated in Table 2 .

Additional blood samples from tigers (7), lions (9) and leopards (3) in nearby enclosures were collected and screened for haemoprotozoans within seven days of the incident. No haemoprotozoans could be detected in the blood smears and wet mounts.

The blood profile of the tigress prior to treatment showed considerable decrease in haematological value $(\mathrm{Hb}, \mathrm{TEC}, \mathrm{PCV}$ and MCHC); biochemical values (serum creatinine, calcium, 
Table 1. Treatment administered to the tigress

\begin{tabular}{|c|c|c|c|}
\hline & Drug/ medication & Volume and route & Frequency \\
\hline \multicolumn{4}{|c|}{ First 3 days } \\
\hline 1. & $\begin{array}{l}\text { Inj. Triquin (Quinapyramine sulphate and Quinapyramine chloride; } \\
\text { Wockhardt Limited) } 2.5 \mathrm{gm} \text { vial diluted in } 15 \mathrm{ml} \text { distilled water }\end{array}$ & $3 \mathrm{ml}$ subcutaneously & Single dose \\
\hline 2. & Inj. Avil (Pheniramine maleate; Intervet India pvt. Ltd) & $4.5 \mathrm{ml}$ intramuscularly & Once daily for 3 days \\
\hline 3. & Inj. 10D (Dextrose injection 10\% w/v; Nirlife Healthcare Ltd.) & $\begin{array}{l}300 \mathrm{ml} \text { intravenously }+ \\
150 \mathrm{ml} \text { subcutaneously }\end{array}$ & Single time \\
\hline 4. & Inj. Xceft (Ceftiofur sodium; Allembic Ltd) & $600 \mathrm{mg}$ intramuscularly & Once daily for 3 days \\
\hline 5. & Inj. Neohepatix (Proteolysed Liver extract; Biological E. Limited) & $4.5 \mathrm{ml}$ intramuscularly & Once daily for 3 days \\
\hline 6. & Glucose mixed water & orally & Ad lib \\
\hline \multicolumn{4}{|c|}{ After 3 days } \\
\hline 1. & Tab Doxitas 100mg (Doxicycline HCL; Intas Pharma) & 10 tab orally & Once daily for 1 month \\
\hline 2. & Tab Liv 52 DS (Himalaya Drugs) & 4 tab orally & Once daily for 1 month \\
\hline 3. & Syrup Dexorange & $30 \mathrm{ml}$ orally & Once daily for 1 month \\
\hline
\end{tabular}

Table 2. Laboratory examination of biological samples of tigress

\begin{tabular}{|c|c|c|c|c|}
\hline & Parameters & $\begin{array}{l}\text { Pre treatment } \\
\text { values }(22 / 01 / 08)\end{array}$ & $\begin{array}{l}\text { Post treatment } \\
\text { values }(20 / 02 / 08)\end{array}$ & References value \\
\hline 1 & $\begin{array}{l}\text { Haemotological parameters } \\
\text { Haemoglobin }(\mathrm{Hb}) \text { gm/dl } \\
\text { Total Erythrocytes count (TEC) } 10^{6} / \mathrm{ml} \\
\text { Packed Cell Volume \% } \\
\text { Mean Corpuscular Volume (MCV) fl } \\
\text { Mean Corpuscular Hemoglobin concentration (MCHC) gm\% } \\
\text { Mean Corpuscular Hemoglobin (MCH) pg } \\
\text { Total Leucocytes Count (TLC) } 10^{3} / \mathrm{ml} \\
\text { Lymphocyte \% } \\
\text { Polymorph \% } \\
\text { Eosinophils \% } \\
\text { Basophils \% } \\
\text { Monocytes \% }\end{array}$ & $\begin{array}{l}12.4 \\
6.52 \\
40.4 \\
62 \\
30.7 \\
19 \\
26200 \\
18 \\
78 \\
2 \\
0 \\
2\end{array}$ & $\begin{array}{l}13.8 \\
6.92 \\
39.4 \\
59 \\
28.7 \\
19 \\
22300 \\
25 \\
70 \\
3 \\
0 \\
2\end{array}$ & $\begin{array}{l}13.60-17.00^{*} \\
6.60-7.43^{\star} \\
41.00-48.00^{\star} \\
59.21-63.63^{*} \\
32.81-38.09^{*} \\
18.32-23.02^{\star} \\
11.6 \pm 3.527^{\wedge} \\
30^{\star \star} \\
63^{\star \star} \\
2^{* \star} \\
- \\
5^{\star \star}\end{array}$ \\
\hline 2 & $\begin{array}{l}\text { Biochemical parameters } \\
\text { Serum Creatinine } \mathrm{mg} \% \\
\text { Serum Calcium mg \% } \\
\text { Serum Phosphorus } \mathrm{mg} \% \\
\text { Serum Bilirubin (Total) } \mathrm{mg} \% \\
\text { Serum Bilirubin (Direct) } \mathrm{mg} \%\end{array}$ & $\begin{array}{l}0.9 \\
7.9 \\
3.7 \\
0.7 \\
0.1\end{array}$ & $\begin{array}{l}0.9 \\
7.9 \\
3.7 \\
0.7 \\
0.1\end{array}$ & $\begin{array}{l}2.7 \pm 0.9^{\wedge} \\
10.6 \pm 0.6^{\star \star} \\
5.5 \pm 1.3^{\star \star} \\
0.2 \pm 0.4^{\wedge} \\
0 \pm 0.1^{\wedge}\end{array}$ \\
\hline 3 & $\begin{array}{l}\text { Serum Protein and Enzymes } \\
\text { Serum Protein } \mathrm{g} \% \\
\text { Serum Albumin } \mathrm{g} \% \\
\text { Serum Globulin } \mathrm{g} \% \\
\text { Aspartate amino transferase (AST) IU/L } \\
\text { Alanine amino transferase (ALT) IU/L } \\
\text { Alkaline phosphatase (ALP) IU/L }\end{array}$ & $\begin{array}{l}7.2 \\
3.6 \\
3.6 \\
23.5 \\
19.7 \\
108\end{array}$ & $\begin{array}{l}7.2 \\
3.6 \\
3.6 \\
35.5 \\
23.7 \\
90\end{array}$ & $\begin{array}{l}7.1 \pm 0.6^{\wedge} \\
3.7 \pm 0.5^{\wedge} \\
3.3 \pm 0.6 \\
11 \pm 2^{\star \star} \\
\mathrm{NA} \\
90 \pm 45^{\star \star}\end{array}$ \\
\hline 4 & $\begin{array}{l}\text { Test for Haemoprotozoans } \\
\text { Trypomastigotes in wet mount and stained blood smears }\end{array}$ & Positive & Not detected & - \\
\hline 5 & $\begin{array}{l}\text { Coprological examination } \\
\text { Parasitic ova/protozoan oocysts }\end{array}$ & Not detected & Not detected & - \\
\hline
\end{tabular}

* - Singh et al. 1999; ^ - Fowler M.E. \& E.R. Miller (2003); ${ }^{* *}$ - Fowler M.E. (1986)

phosphorus levels) as compared to the values recorded for these parameters in healthy tigers (Singh et al. 1999; Fowler 2003). Similar low values were reported in an ailing tigress that succumbed to chronic trypanosomiasis at Sanjay Gandhi Zoological Park, Patna (Singh et al. 2000). There was marked increase in the TLC, polymorphs, serum bilirubin, ALP and AST level indicative of multiple system involvement (e.g. hepatic and renal disorder).

The clinical signs of decreased appetite, weakness, dullness and depression in the present case have been reported by Parija \& Bhattacharya (2001), while typical signs of staggering gait, muscular tremors, bilateral ocular discharge, circling movements, dashing against objects, frequent urination reported by Losos (1980) and Singh et al. (2000) were not encountered.

Marked improvement was noted in haemogram and ALP activity within 48 hours of the treatment. However, AST, ALT and serum proteins including globulin and albumin did not show appreciable changes. No signs of drug toxicity were noted. Following the incident, the husbandry practices (vector control, proper waste disposal, meat inspection, disinfection and sanitation) followed in the VVNP were reviewed.

Since there had been no recent history of animal exchange between facilities or reports of outbreaks of trypanosomiasis in and around the park, it was presumed that the infection might have gained entry through vectors that travelled through fomites, vertebrate pests or infected meat.

Conclusion: A naturally occurring infection with Trypanosome sp. was detected in a tigress from Van Vihar National Park, Bhopal, (M.P.) and successfully treated with quinapyramine salts. Diagnosis was based on microscopic detection of trypomastigotes, and confirmed by positive response to treatment. The rapid clinical treatment and absence 
of trypanosomes in blood smears prepared after treatment indicated that Triquin (quinapyramine sulphate and quinapyramine chloride, Wockhardt Limited) was effective and safe for use in treatment of trypanosomiasis in tigers. This case highlights the utility of regular screening of animals for infectious and parasitic diseases, and effective management for prevention and control of trypanosomiasis.

\section{References}

Coles, E.H. (1986). Veterinary Clinical Pathology. $4^{\text {th }}$ Edition. W.B. Saunders Company, Philadelphia, 486pp.

Fowler, M.E. \& E.R. Miller (2003). Zoo and Wild Animal Medicine. $5^{\text {th }}$ Edition. Elsevier Science (USA). Saunders, Missouri.

Losos, G.J. (1980). Diseases caused by Trypanosoma evansi. A review. Veterinary Research Communications 4: 165-181.

OIE (2005). Trypanosomiasis. Center for Food Security and Public Health. College of Veterinary Medicine, Iowa State University, Ames, Iowa 50011. http://www.cfsph.iastate.edu/Factsheets/pdfs/ trypanosomiasis_african.pdf. Online version dated 3rd August 2005.

Parija, S.C. \& S. Bhattacharya (2001). Tragedy of tigers: Lessons to learn from Nandankanan episode. Indian Journal Medical Microbiology 19: 116-118.

Parashar, B.D., V. Veer, S. Prakash \& V. Kumar (2006). Prevalence of blood sucking flies, vector of trypanosomiasis in the Nandankanan Zoological Park, Bhuvaneswar (Orissa) and their control by integrated pest management. Indian Zoo Year Book IV: 112-125.

Schalm, O.W., N.C. Jain \& J.E. Carroll (1975). Veterinary Hematology, $3^{\text {rd }}$ Edition. Lea and Febiger, Philadelphia.

Singh, A., M. Singh \& U. Shukla (1997). Trypanosomosis (surriosis) in tigress. A case report -Lucknow Zoo. Zoos' Print 12(6): 40-41.

Singh, S., C. Singh, A. Kumar, K.K. Sinha \& P.C. Mishra (1999). Haematology of Tigers (Panthera tigris tigris) Leopards (Panthera pardus) and Clouded Leopards (Neofelis nebulosa) in Captivity. Zoos' Print $\mathrm{XIV}(4): 7-8$

Singh, S., C. Singh, A. Kumar, K.K. Sinha \& P.C. Mishra (2000). Certain Haematological and Biochemical profiles of a white tigress (Panthera tigris Linnaeus) suffering from trypanosomiasis. Zoos' Print Journal 15(2): 207-208.

Swenson, M.J. \& W.O. Reece (1996). Duke's physiology of Domestic animals, $11^{\text {th }}$ Edition. $1^{\text {st }}$ Indian reprint, Panima publishing corporation, New Delhi and Bangalore.

Veer, V. \& B.D. Parashar (2002). Tabanid and muscoid haematophagous flies, vectors of trypanosomiasis or surra disease in wild animals and livestock in Nandankanan Biological Park, Bhubaneswar (Orrisa, India). Current Science 82(10): 500-503.

Ziauddin, K.S., K. Murlidharan \& S.J. Seshadri (1992). Some pathological observations on trypanosoniasis in a tigress at Mysore Zoo. Indian Journal of Wildlife Health Management 1(1): 38-39.

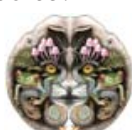

